\title{
2 \\ Fiscal Policy Frameworks in Pacific Island Countries
}

\author{
Paresh Narayan
}

\section{I Introduction}

Historically, economic growth in the PICs has been relatively weak compared with other small island states, such as Mauritius. The economic growth rates for 1996-2005 are presented in table 2.1. Average growth rates over the last decade are below 5 per cent per annum; detailed socio-economic data are provided in appendix 2. In fact, economic growth rates in Fiji, Nauru, Vanuatu, the Solomon Islands and Tonga, have been less than 2.5 per cent per annum.

Table 2.1 Economic growth rate for PICs, 1996-2005

\begin{tabular}{lccccccccr}
\hline & Fiji & Nauru & Tuvalu & PNG & Vanuatu & Kiribati & Samoa & Solomon Islands & Tonga \\
\hline 1996 & 4.8 & -7.3 & -7.1 & 6.6 & 2.5 & -6.6 & 7.3 & 2.5 & 0.0 \\
1997 & -2.2 & -7.3 & 5.6 & -6.3 & 8.6 & 6.8 & 0.8 & -0.6 & -3.2 \\
1998 & 1.3 & -1.9 & 19.7 & 4.7 & 4.3 & 15.3 & 2.4 & 1.0 & 3.5 \\
1999 & 8.8 & -1.9 & -0.5 & 10.1 & -3.2 & 7.0 & 2.2 & -0.2 & 2.3 \\
2000 & -1.7 & -0.1 & 13.4 & - & 2.7 & 4.0 & 6.1 & -14.2 & 5.4 \\
2001 & 2.0 & 0.6 & 5.9 & 2.7 & -2.6 & 4.4 & 7.0 & -8.2 & 7.2 \\
2002 & 3.2 & 0.8 & 1.2 & -0.2 & -7.4 & 2.7 & 1.0 & -2.7 & 1.4 \\
2003 & 1.0 & - & & 2.2 & 3.2 & -1.5 & 3.1 & 6.5 & 3.1 \\
2004 & 5.3 & - & & 2.7 & 5.5 & 2.3 & 3.4 & 8.0 & 1.1 \\
2005 & 0.7 & - & & 3.3 & 6.8 & 2.5 & 5.2 & 5.0 & -2.2 \\
Average & 2.34 & -2.44 & 5.45 & 2.86 & 2.04 & 3.68 & 3.84 & -0.31 & 1.86 \\
\hline
\end{tabular}

Source: Asian Development Bank, 2007 
The PICs have also failed to achieve a sufficient level of private investments to generate economic activity and employment. The successive national development plans of the PICs have stated their objective as achieving private investments of around 20-25 per cent of GDP in order to achieve an economic growth rate of 5 per cent per annum.

In terms of net foreign direct investment, plotted in figure 2.1 for selected PICs over the period 1988-2006, except for Vanuatu which achieved an average net foreign direct investment of around 9 per cent of GDP, for the rest of the PICs this performance is relatively poor. Unfortunately, the average private investment over the last decade has been less than 10 per cent per annum. The other downside of low investment levels is the loss of tax revenue.

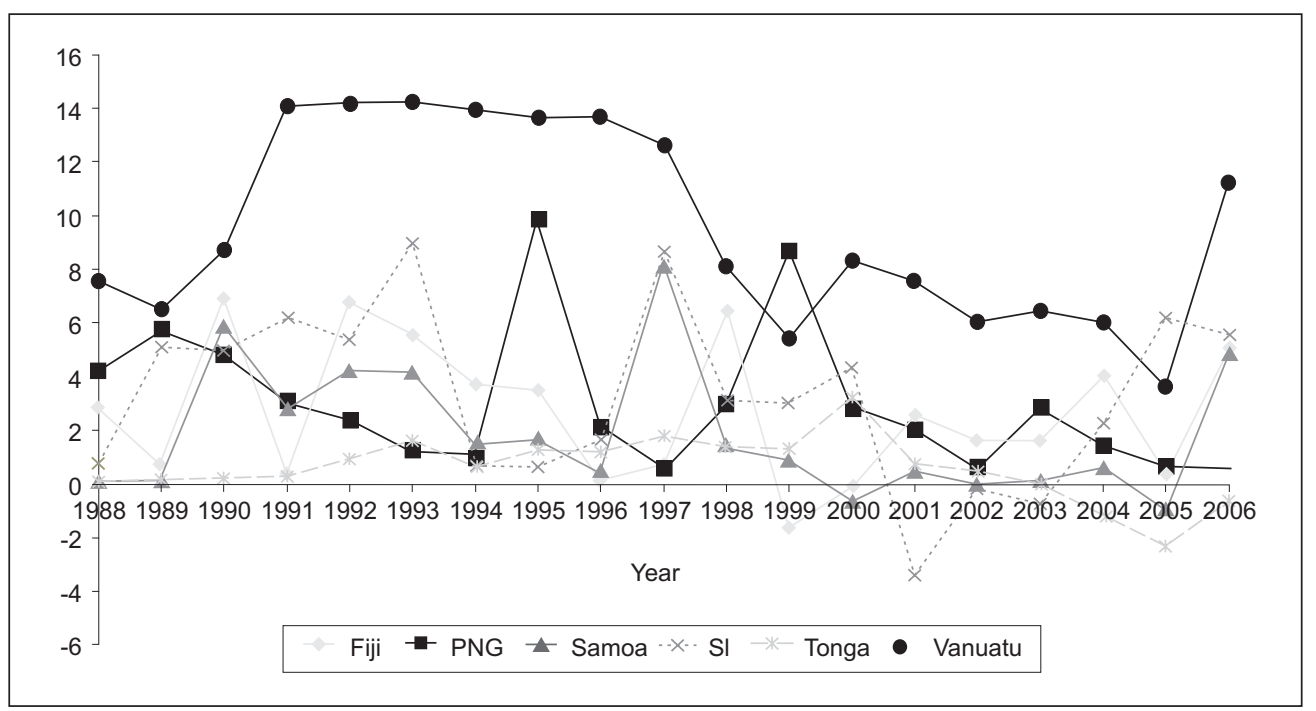

Figure 2.1 Foreign direct investment, net inflows (percentage of GDP)

It is clear that low investments, which in turn contribute to low economic growth, deprive PICs of additional revenue. This has implications for their fiscal policies. The goal of this chapter is to identify some of the key fiscal policy issues and challenges facing the PICs.

In the section 2.1, we outline the key issues and lessons learnt from the fiscal stance of the PICs. In section 2.2, we present an overview of the fiscal policies and strategies of the PICs. In 2.3 we discuss some country specific fiscal strategies adapted by the PICs. In the final section we provide some concluding remarks and policy recommendations.

\subsection{Key issues and lessons learnt}

Some of the main issues that impact on PICs fiscal policies and the success of such policies can be summarised as follows. 
- Slow economic growth rates: historically PICs' economic growth performance has been poor, and over the most recent decade the annual average growth rate has been around 3 per cent. This has not attracted any meaningful private investments, depriving PICs of tax income.

- Persistent budget deficits: in the face of growing demand for public services and a stagnant revenue base, the PICs have had to rely on borrowing to finance their budget deficits. This has led to escalating debts, which have been a drain on fiscal policies and their success.

- Increasing civil service wage bill: this has been a growing concern for many decades. The bulk of government expenditures in many of the PICs goes to paying wages and salaries for the civil servants. In the absence of alternative sources of employment PIC governments, for political as well as social and economic reasons, have traditionally attempted to absorb the labour force into the civil service sector. This has led to a growing civil service. This again affects fiscal policies and their success.

- Political instability and democracy: over the last decade, a number of PICs have experienced political instability in the form of civil unrest and coups. Political instability is a fiscal cost to the PICs. There is loss of economic activity and loss of government revenues from political instability.

Given the issues identified above, it is clear that any success on the fiscal policy front will need to address the issues of slow economic growth, expanding budget deficits and national debts, excessively large civil service, and growing political instability.

\subsection{Fiscal policy strategies in the PICs}

The proliferation of trade agreements since the early 1990s has been notable and poses a number of interesting and difficult questions for the small PICs. An important feature of international trade arrangements between countries has been a significant expansion of regional trade agreements (RTAs) across the global economy. A number of acronyms, such as the WTO, the APEC, the FTAs, the IPPAs, the PICTA, the PACER and the Pacific REPA, have emerged. Some of these agreements are simply free-trade agreements, which involve a reduction in current tariff and non-tariff import barriers so as to liberalise trade in goods and services between countries. The most sophisticated agreement, namely the RTAs, goes beyond traditional trade policy mechanisms to include regional rules on flows of investment, co-ordination of competition policies, agreements on environmental policies, and the free movement of labour.

Although regional and international trading arrangements aim to promote economic integration and allow the members to reap benefits from specialisation, there is also the impact from structural and fiscal adjustment which cannot be avoided. The regional countries are heavily dependent on tariffs as a source of revenue for their government. However, under the regional and international initiatives, for countries to move towards free trade requires gradual removal of tariffs on imports and possibly zero rates of tariff in future. This implication is a fall in the government's revenue base. There is serious concern among regional governments that this tariff removal may place significant financial 
adjustment costs on their respective fiscal systems. This has not motivated the PICs to speed trade liberalisation mechanisms.

In table 2.2 we present some data on customs and import duties and on taxes on international trade for three countries (Vanuatu, PNG and Fiji) for which data is available. In the first panel of table 2.2, evidence suggests that: (i) over the 1990-2006 period, import duties as a percentage of total revenue have declined for all the three countries; and (ii) customs duties still represent a significant share of total revenue: 41 per cent in Vanuatu and 24 per cent in PNG. A similar trend is noticeable in the cases of taxes on international trade. However, in the case of PNG, taxes on international trade have increased over the period 1990 to 1999 . All in all, the data here suggest the historical reliance of PICs on import duties and more generally on taxes on international trade.

If revenue shortfalls occur, however, countries with sound administrative capacity will often be able to recover the losses by strengthening domestic indirect taxes, broadening the tax base, and increasing the efficiency of raising funds for the government (Keen and Ligthart, 2001).

Table 2.2 Customs and import duties, and taxes on international trade

\begin{tabular}{lccc}
\hline Import/customs duties as \% of tax revenue & Vanuatu & PNG & Fiji \\
\hline 1990 & 66.0 & 29.3 & 34.5 \\
$1999 / 2002 / 2006$ & 41.1 & 24.4 & 16.9 \\
\hline Taxes on int. trade as \% of tax revenue & Vanuatu & PNG & Fiji \\
\hline 1990 & 51.3 & 19.5 & 31.6 \\
$1999 / 2002 / 2006$ & 33.6 & 26.4 & 15.9 \\
\hline
\end{tabular}

Source: World Development Indicators, 2007

For the countries that are heavily reliant on tariff revenue, there is likely to be a serious negative effect on gross domestic product as government spending falls in line with the revenue loss, therefore impacting economic and social growth in the PICs.

To minimise the serious social and economic effects of a fall in revenues, the PIC governments need to undertake serious fiscal reforms in order to minimise fiscal disruptions. Baunsgaard and Keen (2005) stress that low-income countries, and particularly the least developed countries (LDCs), frequently lack adequate administrative capacity and a well functioning domestic tax system. They tend to rely heavily on trade taxes as sources of government revenue. Lowering or eliminating tariffs on trade with regional partners, therefore, can constitute a significant risk to a country's fiscal position. One solution available is to amend and restructure the tax and customs system which is perhaps one of the major fiscal adjustments to undertake in order to develop alternative sources of revenue and thus reduce the dependence on tariffs for revenue purposes.

It should be noted that in the PICs, the mechanisms for income tax (both individual and business) collections are weak. A number of studies have highlighted this to be the case and point out that current tax collections are perhaps only 60 per cent of the total 
taxes owed to governments. It follows that one avenue for boosting governments' total tax revenue is to reform the tax collection mechanisms. In Vanuatu, for example, the IMF (2007a) estimates that lost revenue from taxes in 2006 was over 3.5 per cent of GDP.

The PIC governments will be required to implement either a valued added tax (VAT) or some other broad-based consumption tax as a means of broadening their revenue base. Narsey (2003) echoed similar sentiments and recommended the main strategies to the government as: conversion of key import duties to excise taxes (so-called 'sin' items such as alcohol and tobacco taxes, health taxes, and equity taxes); the broadening of the tax system by introducing (where they do not currently exist) consumption-based taxes (such as VAT), income tax (corporate and personal) and compensatory development finance in order to minimise the tax revenue loss from removal of tariffs.

Any increase in taxes or introduction of new taxes may result in, or be perceived to result in, some increase in the cost of living. Moreover, Scollay (1998) reported that 64 per cent of total tax revenue in Kiribati, 57 per cent in Vanuatu, and 46 per cent in Tuvalu came from tariffs; therefore, this considerable amount of revenue through tariffs. The restructuring of the tax system, including the introduction of value-added tax, would incur significant adjustment costs in order to carry out these fiscal reforms.

The revenue resource base is narrow in all PICs. Fiscal revenue in PICs is subject to volatility, particularly with respect to non-tax revenue (for some countries) and grants (for most countries) (see Borgne and Medas, 2007).

Non-tax revenue fluctuates widely as its base is subject to large shocks. Kiribati and Tuvalu are subject to higher volatility as their non-tax revenue as percentage of GDP is significantly larger than for other PICs. The share of non-tax revenue ranges from 50 to 54 per cent of GDP. In 2006, fishing licence fees accounted for 87 per cent of Kiribati's non-tax revenues in 2006 and 43 per cent of government's total revenues. Since the fishing licence fee changes from year to year, we notice high fluctuations in government revenue of Kiribati.

For most of the PICs (including Kiribati, Solomon Islands, and Samoa), half their public financing relies on grants. However, over the past five years, several of these countries have experienced significant rise and fall in grants, so there is a degree of uncertainty with respect to using grants for implementing fiscal policies.

Tax revenue tends to be more stable, but the size of the taxable private sector is often too small to compensate for the large volatility of other revenue sources. Direct tax revenue of PICs averaged about 17 to 25 per cent of GDP over the last decade. In most of the PICs, except for PNG, direct taxes contribute less than 10 per cent of total revenue. Vanuatu does not have direct taxation of any kind, either on personnel or corporate income or real estate duty. Hence, Vanuatu has depended only on indirect taxes.

The personal income tax and corporate income tax rates for selected PICs are provided in table 2.3. PNG has the highest income tax rate at 47 per cent followed by the Solomon Islands (40 per cent). There is relatively more consistency in the maximum corporate tax rate: in most countries it is 30 per cent, with Kiribati having the lowest corporate tax rate (25 per cent). The final column of table 2.3 reports the sales or VAT rates. Again, there seems to be more consistency among the PICs for using sales tax as a means of boosting government 
Table 2.3 Tax rates in selected PICs

\begin{tabular}{lccc}
\hline & Personal income tax* & Corporate income tax & Sales or VAT \\
\hline Solomon Islands & 40 & $30^{* *}$ & $15^{* * *}$ \\
Fiji & 32 & 30 & 12.5 \\
Kiribati & 35 & 25 & 0 \\
PNG & 47 & 30 & 10 \\
Samoa & 29 & 29 & 12.5 \\
Vanuatu & - & - & 12.5 \\
Tonga & 10 & 30 & 15 \\
\hline
\end{tabular}

Notes: ${ }^{*}$ denotes highest income tax bracket; ${ }^{* *}$ denotes corporate tax rates for non-residents is 35 per cent; and

*** denotes that the sales tax rate for rice is 5 per cent and for other consumption goods it is 10 per cent.

Source: IMF (2005)

revenues, with Tonga and the Solomon Islands having a sales tax of 15 per cent and Fiji, Samoa and Vanuatu charging 12.5 per cent. Kiribati is the only country which does not have any sales tax.

The tax systems of the many PICs are complex (including the multiplicity of tax incentive schemes), sometimes regressive, and reliant on trade-related revenues that are likely to decline. These could put pressure, over the medium term, on tariff revenue. Countries such as Kiribati, Solomon Islands and Tonga are most at risk because of their reliance on these types of revenue sources.

Many of the PICs have shifted to VAT from other indirect taxes, such as tariffs and trade taxes. VAT is a tax on consumption, rather than investment, and many orthodox economists supported the shift to VAT because they believe it would not distort incentive to invest as other types of taxes do. Yet VAT is also a tax on the formal sector. It is, therefore, not as effective in countries with large informal sector. This encourages many firms to remain informal while the development of the formal sector remains sluggish.

In addition, tax administrative capacity and compliance are often weak in the PICs, which poses long-term revenue sustainability concerns. The resource base revenue is also likely to decline in some of the PICs. For example, overfishing has gradually reduced revenue from fishing licence fees in Tonga and Kiribati, which in the later case declined from 54 per cent of GDP in 2001 to 28 per cent of GDP in 2006. Similarly, tax concessions and resource depletion are projected to reduce revenue from resource-based sectors, such as mineral and petroleum, in PNG. In some cases, PICs that are dependent on grants are further likely to be constrained as key donors have indicated their intention to cut down budgetary support over time.

The PICs, as a whole, have faced direct and indirect fiscal policy shocks. The direct shock results from the power of trade unions and a weak political economy, leading to large one-off wage settlements. For example, in Fiji the civil service unions were able to negotiate a wage increase of 10 per cent in 2006, and a one-off payment for retroactive pay adjustment. As a result, the civil service wage bill increased by 15.5 per cent in 2006. In 
Kiribati, civil service wages increased by 8.3 per cent in 2005 after a five-year wage freeze. In Samoa, the government increased civil service wages by 42 per cent over a three-year period beginning in 2005. In Vanuatu, after a ten-year wage freeze government increased wages by 20-25 per cent beginning in July 2006.

The growth in wages and salaries has contributed to the growing salary bills in the PICs. In table 2.4, we present a comparison of regional wage and salary expenditures for selected PICs. We notice that the public sector wage bill as a percentage of GDP in the PICs has been almost double that in Asia and middle-income countries, like Malaysia, Mauritius and South Africa (see last two columns of table 2.4). A second observation we make is that the wage bill expenditure as a percentage of GDP is the highest in Vanuatu (12.1 per cent) followed by Fiji (11.5 per cent), the Solomon Islands (9.7 per cent), and PNG (9.2 per cent).

The indirect effect has roots in political instability. Several of the PICs have experienced intermittent periods of political instability. For example, over the period 1990-2006, Vanuatu has undergone 11 changes in government, followed by PNG, which has undergone six changes in government, Solomon Islands with five changes in government, and Fiji which has undergone three changes in government (see table 2.5). The final column of table 2.5 also reports the number of governing parties over the 1990-2006 period, and there is a similarly high frequency of changes. The implication of this government instability, which is effectively a measure of political instability, is the creation of an environment that is not conducive for private investments. Private investments in PICs has been weak; over the last decade (1996-2005), it has averaged less than 10 per cent of GDP against expectations in most PICs for private investments of around 20-25 per cent of GDP. The inability of PIC governments to attract meaningful investments has led to low economic growth rates. A sustained period of low economic growth rate has deprived PICs of the opportunity to expand their revenue base.

Table 2.4 Regional comparison of wage and salary expenditure

\begin{tabular}{lccc}
\hline & $\begin{array}{c}\text { Public wage bill } \\
\text { \% of GDP }\end{array}$ & $\begin{array}{c}\text { Public wage bill as } \\
\text { \% of total expenditure }\end{array}$ & $\begin{array}{c}\text { Public employment as \% } \\
\text { of total employment }\end{array}$ \\
\hline Vanuatu & 12.1 & 53.0 & 26.9 \\
PNG & 9.2 & 29.4 & - \\
Samoa & 8.3 & 24.5 & - \\
Solomon Islands & 9.7 & 24.5 & 27.9 \\
Fiji & 11.5 & 40.6 & 28.2 \\
Asia & 5.3 & 20.0 & 17.2 \\
Middle-income countries & 6.0 & 22.1 & - \\
\hline
\end{tabular}

Source: $\operatorname{IMF}(2005,2007 a)$

In fact, the gap between government revenues and expenditures in PICs has widened over the last decade. In other words, there has been an escalation of government deficits (see figure 2.2). Except for Kiribati, which has experienced budget surpluses (see figure 2.3), the rest of the countries have experienced persistent deficits over the period 1989-2005. 
Table 2.5 Political environment, 1990-2006

Number of changes in government

Number of changes in governing parties

\begin{tabular}{lll}
\hline Fiji & 3 & 4 \\
PNG & 6 & 6 \\
Samoa & 2 & 0 \\
Solomon Islands & 5 & 6 \\
Vanuatu & 11 & 5 \\
\hline
\end{tabular}

Source: IMF (2007b)

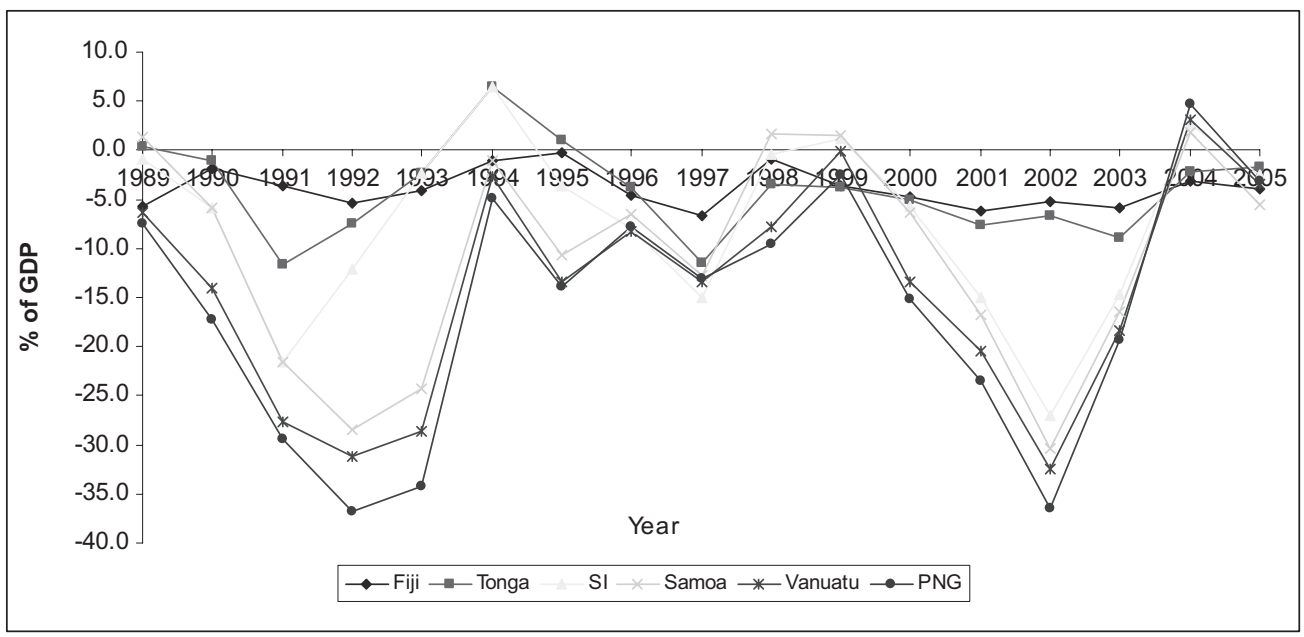

Figure 2.2 Government deficits as a percentage of GDP, 1989-2005

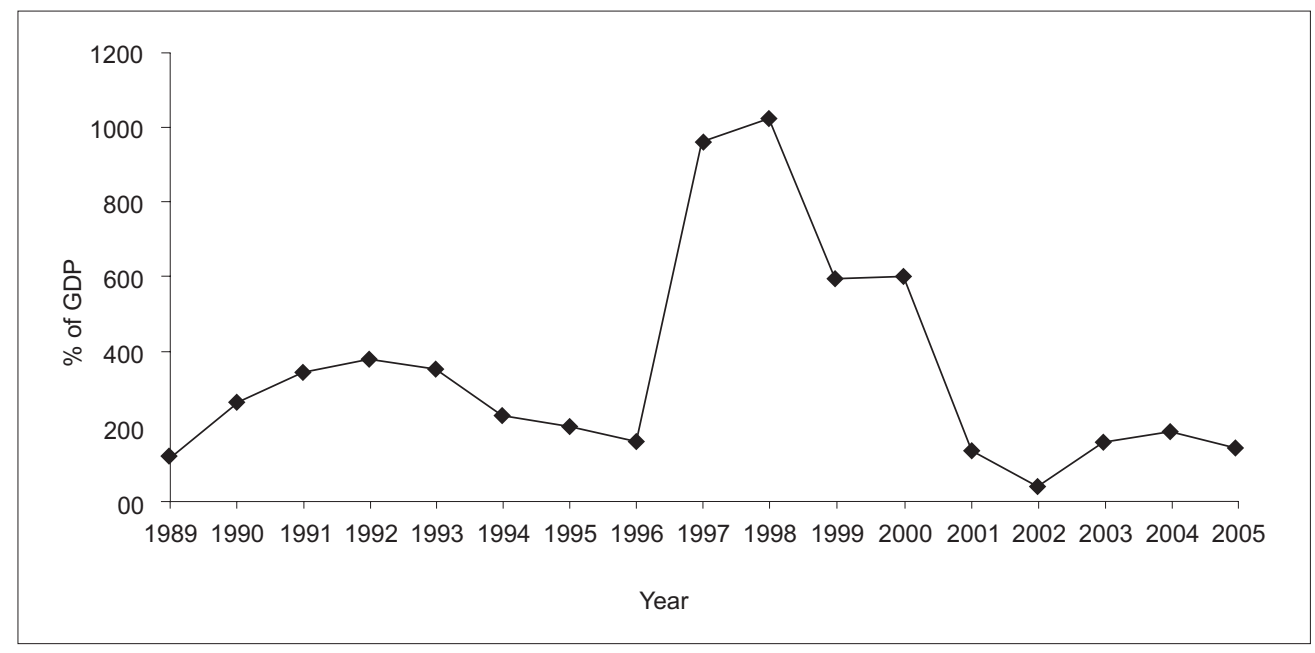

Figure 2.3 Government deficit as a percentage of GDP for Kiribati, 1989-2005 
The fiscal space of PICs is greatly hampered by lack of economic activities, as reflected in their low private investment and low economic growth rates. Among the key reasons behind low private investments, apart from political instability as highlighted above, are the high cost of doing business in PICs and the absence of rule of law. Some selected indicators of business cost and rule of law are presented in table 2.6.

Table 2.6 Selected indicators of business costs and governance constraints

\begin{tabular}{lcccc}
\hline & $\begin{array}{c}\text { Starting a business } \\
\text { (cost as \% of income } \\
\text { per capita) }\end{array}$ & $\begin{array}{c}\text { Dealing with licences } \\
\text { (cost as \% of income } \\
\text { per capita) }\end{array}$ & $\begin{array}{c}\text { Enforcing contracts } \\
\text { (rank out of 175) }\end{array}$ & $\begin{array}{c}\text { Kaufman's rule of } \\
\text { law index } \\
\text { (from - 2.5 to 2.5)* }\end{array}$ \\
\hline New Zealand & 0.2 & 27.2 & 15 & 1.93 \\
Australia & 1.8 & 13.8 & 7 & 1.83 \\
Palau & 4.9 & 6.8 & 151 & 0.77 \\
Mauritius & 8.0 & 13.7 & 109 & 0.82 \\
Seychelles & 9.1 & 51.3 & 73 & -0.03 \\
Tonga & 10.3 & 174.6 & 126 & 0.18 \\
Marshall Islands & 18.1 & 37.6 & 103 & -0.22 \\
Fiji & 25.8 & 41.7 & 86 & -0.09 \\
PNG & 28.2 & 110.0 & 88 & -0.76 \\
Samoa & 45.5 & 105.1 & 54 & 0.84 \\
Kiribati & 50.0 & 545.2 & 136 & 0.36 \\
Solomon Islands & 68.9 & 501.1 & 102 & -1.01 \\
Micronesia & 135.9 & 21.3 & 139 & 0.44 \\
\hline
\end{tabular}

Notes: *Minus 2.5 is the lowest and 2.5 the highest score.

Source: IMF (2007c)

The performance of PICs is weak relative to both developed countries in the region such as Australia and New Zealand and developing countries such as Mauritius. For example, the cost of starting a business in Fiji is three times higher than Mauritius and over five times more expensive than Mauritius in Samoa, Tonga, Kiribati, PNG, and Solomon Islands. In terms of enforcing contracts, PICs are ranked very low. Obtaining licences for business are equally expensive in PICs and they perform poorly on the rule of law index.

\section{Environmental and economic vulnerability}

The role of economic vulnerability arising from natural disasters is eloquently discussed in Adrianto and Matsuda (2002). Briguglio (1995) discusses a wide range of issues that make small states including PICs economically vulnerable; these factors include small size, limited endowment of natural resources, narrow export base, limited scope to exploit economies of scale, monopolies in key economic and service sectors making domestic firms and suppliers 
inefficient and costly; proneness to natural disasters which affects commodity (particularly agricultural) supply commitments, lack of human capital, among others (see also Hein, 1990). Of the limited natural resources that these small states posses, there is a danger of resource depletion. Briguglio (1995) points out the cases of resource depletion in Fiji (gold), Vanuatu (manganese), Nauru (phosphate), and Trinidad and Tobago (oil). The implication for fiscal policy and indeed success is clear here. Natural resources, by virtue of making up a significant proportion of exports, are a source of government revenue. A decline in government revenue through resource depletion has negative implications for fiscal expenditures; see table 2.7 for the vulnerability index for selected PICs.

Table 2.7 Vulnerability of small states

\begin{tabular}{lcccc}
\hline Country & Output volatility index & Rank & Composite vulnerability index & Rank \\
\hline Vanuatu & 3.61 & 90 & 13.29 & 1 \\
Tonga & 13.18 & 4 & 10.44 & 3 \\
Fiji & 6.84 & 32 & 8.89 & 8 \\
Solomon Islands & 11.21 & 9 & 8.34 & 11 \\
Samoa & 6.92 & 30 & 7.37 & 20 \\
Kiribati & 16.6 & 1 & 5.08 & 59 \\
\hline
\end{tabular}

Source: Commonwealth Secretariat (2000: table 2)

The fiscal space of PICs is impacted by the inherent environmental vulnerability of Pacific island states. Changes relating to the atmosphere and the ocean, triggered in large part by the El Nino phases, are particularly damaging for island countries. In the Pacific, Pelling and Uitto (2001) report that El Nino events have resulted in water shortages and drought in PNG, Marshall Islands, Micronesia, American Samoa, Samoa, Tonga, Kiribati, and Fiji.

Moreover, they argue that islands such as Tuvalu, Tonga, Samoa, the Cook Islands, and French Polynesia are more prone to cyclones. The greater degree of environmental vulnerability is a burden to the fiscal space of PICs. PICs already faced with fiscal imbalances are unable to respond effectively to challenges posed by environmental vulnerability. In some countries, the need to address environmental vulnerability is diverting key resources away from capital investments, thus further straining fiscal space of PICs.

Tisdell (2008) argues that while all Pacific island nations and territories will be adversely affected by sea-level rise, the extent and nature of its impact will vary with their geographical features. He points out that Kiribati and the Marshall Islands are most at risk of becoming uninhabitable as a result of sea-level rise. Tisdell (2008) convincingly argues that Pacific island states which have reasonably raised atolls or consist of high islands, such as Samoa and Tonga, are likely to be less affected by sea-level rise. Some countries, such as Fiji, PNG, the Solomon Islands, and Vanuatu, he argues, have enough high raised islands to relocate people from land lost to sea-level rise. However, he points out that in many of these countries, the low-lying areas are areas of high population density and economic activity. It follows that 
from a fiscal policy point of view, this sea-level rise and the ensuing loss of productive land will be a further fiscal constraint (see also Mimura, 1999).

\section{Impact of poverty on fiscal space}

In tables 2.8 and 2.9 we report some social indicators for PICs. Based on data on HDI and HPI, they show that PICs have performed poorly. This is further reflected in poverty figures reported in table 2.9. Poverty levels are relatively high in the PICs. This implies that a lot of resources are needed to fight poverty and low standards of living in the PICs. This is a strain on government's budget and often social development in terms of fighting poverty and improving health and education status in the PICs is given less emphasis, mainly due to lack of financial resources. In large part, much of the development work relating to social development is contingent on donor assistance and NGO work.

Table 2.8 HDI and HPI indicators for Pacific island countries

\begin{tabular}{lccccc}
\hline & & \multicolumn{2}{c}{ HDI } & \multicolumn{2}{c}{ HPI } \\
\cline { 2 - 6 } Country & $1980 s$ & 1998 & rank & 1998 & rank \\
\hline Palau & 0.635 & 0.861 & 1 & 108 & 8 \\
Cook Is & - & 0.822 & 2 & 6.1 & 3 \\
Niue & - & 0.774 & 3 & 4.8 & 1 \\
Fiji & - & 0.667 & 4 & 8.5 & 6 \\
Nauru & - & 0.663 & 5 & 12.1 & 9 \\
Tonga & - & 0.647 & 6 & 5.9 & 2 \\
Samoa & - & 0.590 & 7 & 8.6 & 7 \\
Tuvalu & 0.495 & 0.583 & 8 & 7.3 & 4 \\
FSM & - & 0.569 & 9 & 26.7 & 12 \\
Marshall Is & - & 0.563 & 10 & 19.5 & 11 \\
Kiribati & 0.279 & 0.515 & 11 & 12.6 & 10 \\
Vanuatu & - & 0.425 & 12 & 46.6 & 13 \\
Solomon Is & 0.179 & 0.371 & 13 & 49.1 & 14 \\
PNG & 0.224 & 0.314 & 14 & 52.2 & 15 \\
Tokelau & n.a & n.a & n.a & 7.6 & 5 \\
\hline
\end{tabular}


Table 2.9 Poverty headcount ratio (\% of population below the national poverty line)

\begin{tabular}{lcccc}
\hline \multirow{2}{*}{ Country } & \multicolumn{4}{c}{ MDGI $1 b: \%$ of population below basic needs poverty line } \\
\cline { 2 - 5 } & National & Urban & Rural & Year $\mathcal{E}$ source \\
\hline Cook Islands & 12.0 & - & - & 1998 HIES \\
Fiji & 25.5 & 27.6 & 24.3 & $1990 / 91$ HIES \\
& 34.4 & 31.8 & 38.1 & $2002 / 03$ HIES \\
Kiribati & 50.0 & 51.0 & 50.0 & 1996 HIES \\
Marshall Is & 20.0 & - & - & 1999 Census \\
FSM & 27.9 & 29.5 & 32.9 & 1998 HIES \\
PNG & 37.5 & - & - & 1998 HIES \\
Samoa & 20.3 & 23.3 & 17.9 & 2002 HIES \\
Solomon Is & 22.7 & 32.2 & 18.8 & $2005 / 06$ HIES \\
Tonga & 22.3 & 23.6 & 22.8 & 2001 HIES \\
Tuvalu & 29.3 & 23.7 & 23.4 & 1994 HIES \\
& 25.9 & 29.8 & 24.7 & $2004 / 05$ HIES \\
Vanuatu & 40.0 & - & - & 1998 HIES \\
\hline
\end{tabular}

Source: Secretariat of the Pacific Community (2004)

In a very detailed study of the challenges facing small states, Winters and Martins (2004) argue that on average micro and very small economies face huge competitive challenges. They point out that the environment in these countries is weak to the extent that these economies are unsuitable for industrial and in some cases tourism development. While some policy responses have been geared towards subsidising business investments in these countries in order to obviate the cost disadvantages of smallness, Winters and Martins (2004) argue against such a policy option. Their alternative is to search for another source of income, preferably from donors, which is likely to improve and make efficient infrastructure and utilities. They point out, however, that this is part of the challenge. The much broader challenge is rooted in higher shipping costs and thin markets for skills. Their solution for circumventing this is to allow small countries' exports to sell at tariff inclusive prices in industrial country markets rather than at world market prices. In sum then, the work of Winters and Martins (2004) provides a very clear picture of the situation in the PICs: the cost of doing business is relatively high. This coupled with intermittent political and or economic policy uncertainty is a constraint on government budgets, thus rendering a fiscal policy burden.

The role of fiscal policy in the PICs is large and challenging. Chowdhury and Vidyattama (2007) argue that in light of poorly developed infrastructure and lack of human resources, the role of governments in economic development in PICs is large, implying the importance of fiscal policy. Fiscal policy, through reductions in taxes (both private and corporate - direct and indirect), are used to stimulate consumption and investment. However, the impact of 
tax policy is relatively mild given that most PICs suffer from weak investment and, generally speaking, unstable macroeconomic environment. These are not conducive for tax policies to prosper. Hence, generally speaking, taxation policies aimed at boosting investments and economic growth have failed. That fiscal policy is predominant in the region and that it has failed to achieve economic growth has come at a cost, that being high budget deficits which have resulted in escalating national debts.

One feature of urban development in PICs is urbanisation. With structural reforms in the PICs, and with greater emphasis on cash income, rural to urban migration has taken place. The speed of urbanisation has increased with globalisation. This has seen a shift away from agricultural production towards manufacturing and in particular service sectors, of which tourism is the key sector. Now, tourism has become one of the main sources of employment and income for many PICs. Urbanisation has exerted pressure on local and central governments for urban management of not only roads and utilities but also of housing. Generally speaking, there has been a lack of success on the part of the state to provide appropriate housing for rural to urban migrants, sparking an expansion in squatter settlements. This has put pressure on governments' scarce resources.

The advent and indeed growth of squatter settlement has been to a large extent responsible for the growth of the informal sector. The informal sector in the PICs is growing and in some countries, such as Fiji, it is large. In Fiji, for instance, Chand (2002) reports that in 1996 almost 37 per cent of the economically active population was engaged in the informal sector. In 1996 national poverty rate was amount 20 per cent, by 2007 it had reached 40 per cent. Given that poverty gives rise to the informal sector, it is reasonable to assume that over 50 per cent of Fiji's population is engaged with the informal sector. In addition, Reddy et al. (2006) report that informal sector employment is around 51 per cent of total employment.

\subsection{Country case studies}

Several PICs have sought to reduce their public finance by implementing difficult structural reforms. For example, starting in 1994, Samoa embarked on a politically difficult but highly effective and sustainable expenditure-led fiscal consolidation (combined with reform aimed at improving the efficiency of the tax system and revenue collection) coupled with structural reforms (including privatisation). Likewise, the Fiji government beginning in 1988 took a number of initiatives such as corporatisation and privatisation of public enterprise activities as a primary approach to reducing public outlays for quasi-commercial activity. In 1996, the government established the public enterprise and public sector reform. The primary objective of this unit was to facilitate the implementation of the public enterprise reform programmes as well as monitor the performance of the public enterprises. The government introduced a performance management system to replace the system of cost of living adjustments. Under this new system, employees were to be rewarded based on their performance rather than receiving an automatic annual pay increase. However, the unions have opposed the implementation of the scheme. In 2004, the government also abolished all permanent secretary posts of the government ministries and introduced chief executive (CEO) positions on a 
contract basis. In 2007, fiscal consolidation measures were implemented and included: (a) a reduction of the operating expenditure through trimming the number of ministries and departments from 36 to 16, (b) cutting wages and salaries of civil servants by 5 per cent across the board; and (c) downsizing the civil service by lowering the retirement age and freezing all vacant civil service positions.

In 1997 the Vanuatu government approved an overarching programme of public sector reform to stabilise the budget while improving the quality of governance: the former was to be achieved via downsizing of the public sector, while the latter was to be achieved by increasing transparency and accountability in public sector management.

Similar reform policies were adopted by the Tongan government. In 2004, heads of the departments were placed on contracts with associated performance indicators. Reforms of the public enterprise were also undertaken.

Papua New Guinea and Solomon Islands are examples of countries that partly reduced vulnerability by undertaking fiscal adjustments. Some of the reforms introduced by Papua New Guinea government in the post-1980 period were as follows:

- The 1982/83 retrenchments (redundancies), and the Public Service (management) Act 1986, which redefined the role and powers of the Public Service commission, then created the department of personnel management, increased delegation of responsibilities to the department heads, introduced contracts for senior staff, and created a system of performance management;

- The abolition in 1986 of the national public expenditure planning system and introduction of the medium-term development strategy (MTDS) and public investment programme (PIP) system including the project cycle process;

- The 1987 resource management system (RMS); and

- The 1999 functional and expenditure review and a public service retrenchment programme associated with the 1999 budget.

Similarly in Solomon Islands, public service reform: the programme instigated by the government since 1997 has resulted in the trimming of the civil service. In 1998, the government made commitments to its debt servicing, ensuring that there were no interest arrears.

Since 1995, the Tuvalu government has also undertaken reform of the public sector including the corporatisation and privatisation of the government business.

With the escalation of public debts over the years, governments of the PICs understand the critical importance of having effective debt management strategies in place to both reduce the size of debt and maintain consistency in debt serving obligation.

For instance, the Fiji government is committed to pursuing its debt levels target of 45 per cent of GDP over the medium term. This will be achieved through consistent reduction in deficits with the ultimate aim of registering a balanced budget in the medium term. Debt policy is committed to improving the issuance of domestic and foreign debts to reduce loan servicing cost. The government is working towards strengthening its cash flow management in order to provide a more transparent and systematic approach to borrowing. With better and enhanced cash flow techniques, government should be able to borrow within the approved ceiling and also ensure sufficient support for contingencies and priority 
expenditures. External debt management strategies are refined regularly to reduce exchange rate losses and other costs associated with borrowing abroad.

A similar approach is taken by the Vanuatu government. Since the capital market is shallow, any rollover of domestic debt could theoretically represent a fiscal risk to cash management. The government is making efforts to retire any domestic debts. For example, in 2003, the government used cash surplus to retire one domestic debt and eliminate its overdraft at the reserve bank of Vanuatu. In other words, Vanuatu used its savings to reduce the debt burden.

Other debt management strategies undertaken by PICs are: making commitments to debt repayment, assuring that there are no arrears on interest rates, and setting fiscal benchmark to achieve fiscal consolidation.

\subsection{Financial crisis and the PICs}

The global economic and financial situation has worsened to the extent that it is, among some analysts at least, considered worse than the 1930s' Great Depression. The credit crisis, which started from the USA, has spread to other developed countries, and this is affecting trade and other economic relationships between developed countries and their trading partner countries.

In terms of where the PICs stand relative to the global financial crisis, it is still early days yet since the impact of the full crisis has not yet flowed on to small island countries. The impact may come sooner rather than later since most of the PICs' major trading partner countries, such as the USA, Western Europe, Japan, and New Zealand, are already in recession. If the recession persists then the following impacts are likely to be felt by the PICs.

Tourism: the PICs, most of them, depend in large part on tourism as their main export activity. For these PICs the main source of tourists is the industrialised world: Australia, New Zealand, the USA, Japan, and Europe. And, since most of these countries are in recession, as the real impact of these recessions is felt, residents of these countries will reduce their travel for leisure. This will reduce the number of tourists visiting the PICs, thus negatively affecting foreign reserves, employment and incomes in the PICs (table 2.10).

Remittance: remittances have grown steadily for the PICs. In Tonga, remittances make up around 39.3 per cent of GDP. Remittances as a percentage of GDP are significant for Samoa (25.5\%) and Kiribati (15\%). For almost all PICs, remittances as a percentage of GDP have increased over the 1997-2005 period. A plot of the trend in remittances is presented in figure 2.4. Except for Vanuatu, an upward trend in remittances (measured in US dollars) is noticeable.

Aid: the PICs have a history of dependence on aid, both cash and in-kind, to fund a range of development activities. The official development assistance (receipts) for selected PICs is reported in table 2.11. Two observations are worth making. First, the ODA over the period 1997 to 2003 has increased for all countries except for PNG and Tonga, although in the case of Tonga only a marginal decline is observable. In 2002, the latest year for which consistent data are available, ODA per capita was highest for Niue at close to US\$5,000 per year, followed by Nauru (around US\$1,600). A large proportion of the ODA receipts 
come from Australia and New Zealand. That Australia and New Zealand, as a result of the financial crisis, are in a recession does not argue well for the PICs. In light of this recession, the donors are likely to cut back on ODA to the PICs. This is likely to negative impact development work in the region.

In terms of policy reactions to the financial crisis, the PICs have not acted yet. This is not surprising. The full impact of the crisis has not been felt yet. Most importantly, the stimulus packages that have been implemented by countries like the USA and Australia will have implications for PICs. The hope is that these fiscal measures adopted by the major trading partner countries of the PICs will negate the negative repercussions of the crisis.

Table 2.10 Selected statistics on tourism, 2007

\begin{tabular}{lccc}
\hline & Ranking $^{*}$ & Contribution to GDP & Employment (\% of total employment) \\
\hline Solomon Islands & 117 & 3.1 & 7.7 \\
Fiji & 19 & 10.3 & 24.5 \\
Kiribati & 156 & 5.4 & 4.4 \\
PNG & 159 & 5.3 & 4.3 \\
Tonga & 53 & 13.8 & 12.0 \\
Vanuatu & 10 & 38.8 & 34.9 \\
\hline
\end{tabular}

Notes: * relative contribution to national economies

Table 2.11 ODA receipts from all sources for Pacific island countries (US\$ million per annum)

\begin{tabular}{lcccc}
\hline Country & 1997 & 2000 & 2003 & $\begin{array}{c}\text { ODA per capita } \\
\text { (2002; US\$ per annum) }\end{array}$ \\
\hline Cook Islands & 10.1 & 4.0 & 5.8 & 321.7 \\
Fiji Islands & 44.5 & 29.0 & 51.1 & 65.9 \\
Marshall Islands & 62.9 & 57.0 & 56.5 & 967.5 \\
Nauru & 2.6 & 4.0 & 16.1 & 1599.6 \\
Niue & 5.3 & 3.0 & 8.9 & 4977.6 \\
PNG & 346.4 & 272.0 & 220.8 & 42.53 \\
Samoa & 27.4 & 27.0 & 33.0 & 186.74 \\
Solomon Islands & 41.8 & 68.0 & 60.2 & 147.2 \\
Tonga & 27.6 & 19.0 & 27.5 & 281.23 \\
Vanuatu & 27.2 & 46.0 & 32.4 & 173.6 \\
\hline
\end{tabular}

Source: PIFS (2005) 


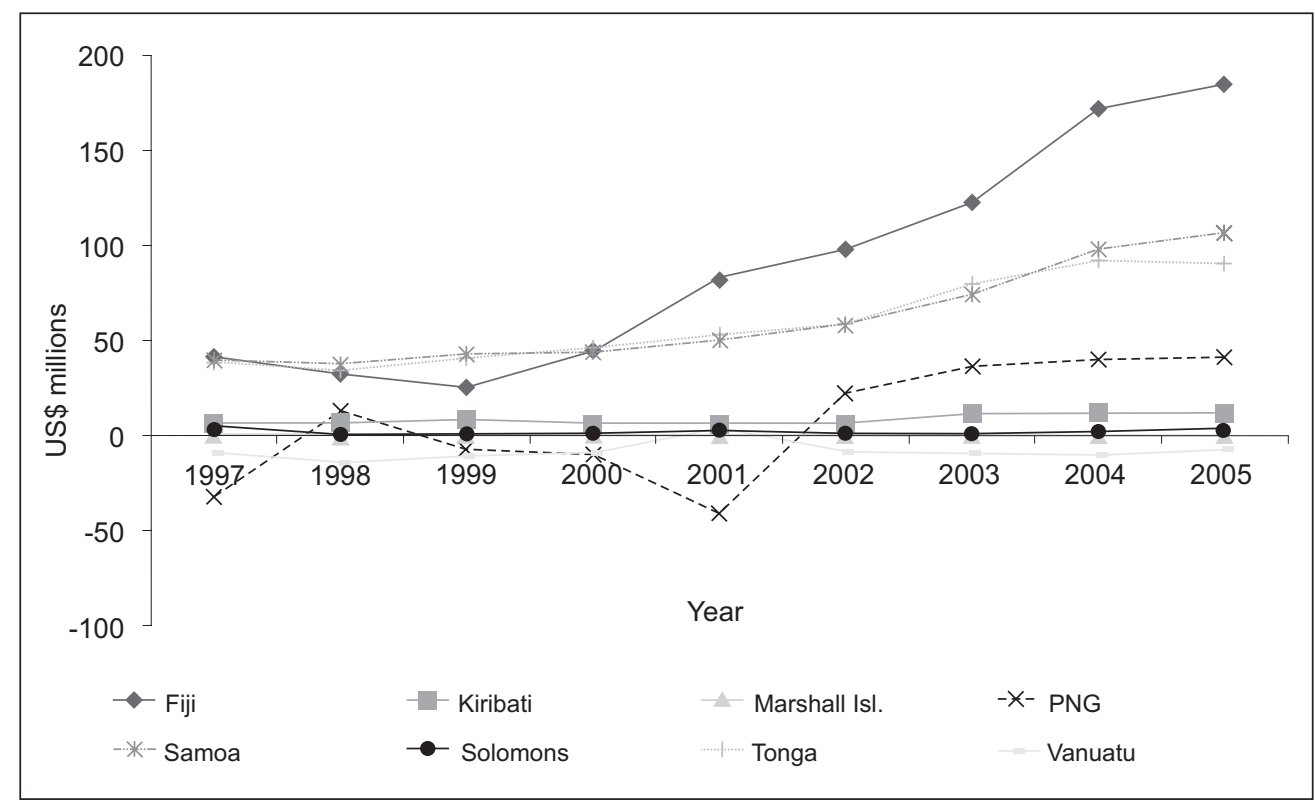

Figure 2.4 Trends in remittance for selected PICs, 1987-2005

Source: Data extracted from Browne and Mineshima (2007)

\subsection{Conclusions and recommendations}

There is a need to develop additional revenue sources. At present, given constraints for private investments, the PICs are unable to reap revenues from a wide range of sources. Developing appropriate incentives for export-oriented products including service sector activities, such as information, communications and technology, will increase business activity, provide employment for locals, and together will increases government's revenues from both corporate and individual income taxes and from production and consumption related taxes such as the VAT.

There is a need to ensure financial stability. It is true that the PICs have performed poorly in terms of a sustained period of low economic growth. It is equally true that much of this growth has been consumption driven, which is perceived to be unsustainable. Since the bulk of consumption goods are imported, the bulk of the spending on consumption goods is not on locally produced goods. This means that despite high consumption expenditures, government is only able to collect revenue from import duties. With trade liberalisation, there is a serious concern that income from import duties will decline; this has already started taking place, putting fiscal strain on the PICs. One way out of this situation is to encourage domestic production of those goods in which PICs have a clear comparative advantage, including stimulating their tourism and related service industries. This will minimise the impact of revenue loss from import duties and boost government's revenues from the local economy through fiscal measures (income tax and VAT collections). 
There is a need to build fiscal space. With growing demand for social services and a stagnant revenue base, the PIC governments' budget deficits have persisted for a long time period. To meet their spending obligations, the PIC governments have relied on domestic and external funding, thus leading to large and escalating debt levels, which in the PICs stands between 40-70 per cent of GDP. There is a need for more prudent expenditure allocation, away from consumption-based activities to capital investments. This will create fiscal space for higher development spending.

The high and rising civil service wage/salary bill needs to be reduced. For over a decade, calls have been made, both from domestic policy-makers and international organisations such as the International Monetary Fund and the Asian Development Bank, for reforms of the civil service sector. The bulk of governments' expenditures go to civil service wages and salaries, and there is a need to control wage and salary bills to provide fiscal space for expenditure allocations to capital projects.

There is a need to improve public financial management. Corruption, poor governance, lack of accountability and transparency are crucial issues in the PICs management of public finance. On any ratings on corruption and governance, the PICs perform poorly. Mismanagement of public finances is common. The PICs need to implement stringent measures to deal with mismanagement of public finances. This will ensure more efficiency in not only revenue collections but also in project implementation and outcomes. This will ensures greater fiscal space and capacity.

The trade agreement initiatives by regional countries is often seen as beneficial to the trading partners but most regional trade agreements do not foresee or implement provisions for revenue sharing or revenue loss compensation. This often has an adverse impact on their fiscal balance as they cannot rely on designated resources from regional partners; therefore, to cope with the revenue shortfalls complementary policy reforms have to be undertaken. Reforms in the areas of customs collection through better compliance with existing regulations is one way to offset the revenue losses or a more comprehensive reform measures such as broadening of the tax base to shift revenue generation away from trade taxes is the other option. Such fiscal reforms are not easy to design and implement because these fiscal reforms come at a serious adjustment costs. The cost aspect needs to be considered thoroughly.

There is a need to build a stable political environment and respect for rule of law which will ensure an environment conducive for economic growth. A stable political environment with respect for rule of law will boost fiscal space of the PICs.

Finally, a key determinant of fiscal space is the cost of doing business. Our analysis revealed that starting a business in PICs is extremely costly compared with neighbouring developed countries and other developing countries. It follows that there is a need to reform institutions that have the responsibility of dealing with investors.

\section{References}

Adrianto, L and Y Matsuda (2002). 'Developing economic vulnerability indices of environmental disasters in small island regions', Environmental Impact Assessment Review, 22, 393-414. 
Baunsgaard, T and M Keen (2005). ‘Tax Revenue and (or?) Trade Liberalization' Working Paper WP/05/112, Washington, DC: International Monetary Fund,.

Borgne, EL and P Medas (2007). 'Sovereign Wealth Funds in the Pacific Island Countries: Macro-fiscal Linkages', Working Paper, WP/07/297, Washington, DC: International Monetary Fund.

Briguglio, L (1995). 'Small Island Developing States and their Economic Vulnerabilities', World Development, 23, 1615-1632.

Browne, C and A Mineshima (2007). 'Remittances in the Pacific Region', Working Paper WP/07/35, Washington, DC: International Monetary Fund.

Chand, G (2002). 'The informal sector in Fiji', Memo: Paper prepared for the Trade Union Congress, Suva.

Chowdhury, A and Y Vidyattama (2007). 'Macroeconomic Policies for Growth in Small Pacific Island Economies', UNU-WIDER Research Paper No.2007/24.

Commonwealth Secretariat (2000). Small states: meeting challenges in the global economy, Report of the Commonwealth Secretariat/World Bank Joint Task Force on Small States, London: Commonwealth Secretariat.

Hein, PL (1990). 'Economic Problems and Prospects of Small Islands' In Beller, W, P d'Ayala and P Hein (eds) Sustainable Development and Environmental Management of Small Islands Paris, France: Parthenon Publishing, pages 35-44.

International Monetary Fund (IMF) (2005). Solomon Islands: 2005 Article IV Consultation - Staff Report; and Public Information Notice on the Executive Board Discussion, IMF Country Report No. 05/365, Washington, DC: International Monetary Fund.

IMF (2007a). Vanuatu: 2006 Article IV Consultation-Staff Report; and Public Information Notice on the Executive Board Discussion, IMF Country Report No. 07/92, Washington, DC: International Monetary Fund.

IMF (2007b). Vanuatu: Selected Issues, IMF Country Report No.07/93, Washington, DC: International Monetary Fund.

IMF (2007c). Solomon Islands: 2007 Article IV consultation-Staff Report; Staff Supplement; and Public Information Notice on the Executive Board Discussion, International Monetary Fund Country Report No. $07 / 304$.

Keen, M and J Ligthart (2001). 'Coordinating Tariff Reductions and Domestic Tax Reform' Journal of International Economics 56: 407-25.

Mimura, N (1999). 'Vulnerability of island countries in the South Pacific to sea level rise and climate change', Climate Research, Vol 12, pp 137-43.

Narsey, W (2003). 'Trade Liberialisation and Fiscal Reform: Towards a negotiating framework for Economic Partnership Agreements with the European Union', Report prepared for the South Pacific Forum Secretariat, Suva, Fiji.

Pelling, M and JI Uitto (2001). 'Small Island Developing States: Natural Disaster Vulnerability and Global Change', Environmental Hazards, 2, 49-62.

PIFS (2005). Aid effectiveness to the Pacific region: A focus on skills transfer, capacity building and technical assistance, Suva: Pacific Islands Forum Secretariat.

PIFS (2008). 'Forum Economic Action Plan 2008', Forum Economic Ministers' Meeting, Port Vila, Republic of Vanuatu. 
Reddy, M, V Naidu and M Mohanty (2006). 'The urban informal sector in Fiji: Results from a survey', Fijian Studies, 1, 127-154.

Scollay, R (1998). 'Free Trade Options for the Forum Island Countries', Report prepared for the South Pacific Forum Secretariat, Suva: Forum Secretariat.

Secretariat of the Pacific Community (2004). Pacific Islands Regional Millennium Development Goals Report, Noumea, New Caledonia: Secretariat of the Pacific Community and UNDP.

Tisdell, C, (2008). Global warming and the future of Pacific Island countries, International Journal of Social Economics, 35, 889-903.

Winters, A, and P Martins (2004). Beautiful but costly: Business costs in small remote economies, Economic Paper 67, London: Commonwealth Secretariat.

World Bank (2007). World Development Indicators, Washington, DC: World Bank. 